\title{
Syntheses and Selective Peptide-binding Properties of Metallomacrocycles
}

\author{
Kum Hee Lec and Seung Soo Yoon" \\ Deparment of Chemistr, SungKyunKwan University. Staton 470-746, Korea \\ Receined Angust 14. 2003
}

Key Words : Metallomacrocycle, Peptide-binding, Molecular recognition

The development of selective synthetic receptors and thus elucidation the basic rules that govern intermolecular interactions between receptors and substrates is of great importance for improved understanding of molecular recognition mechanisms seen in biological systems and the potential applications to synthetic, separative and analytical purposes.' Although it is known that several synthetic receptors bind with the certain substrates selectively, the search for novel synthetic receptors is continuing. ${ }^{2}$ Here, a series of novel macrocyclic compounds (1 and 2) were synthesized and its sequence selective peptide-binding properties were elucidated by solid phase color assay using encoded combinatorial library of polypeptides.

Macrocyclic compounds ( 1 and 2 ) have the well-defined. potential substrate binding cavities having the convergent hydrogen bonding donoriacceptors and the hydrophobic aromatic surfaces. Particularly, in macrocylic compounds (1 and 2), metal acts to maintain macrocyclic structure and thus makes the receptor to be preorganized for the effective complexation with the corresponding substrates. Besides. certain metals can offer the following advantages: (I) changes in the coordination number and geometry of different metals can allow a modification of the shape of templated receptor sites, (2) certain metals can act both to organize receptor site formation, and as catalytic center for subsequent reaction on a bound substrate as seen in metalloenzyme, (3) upon complexation with a substrate.

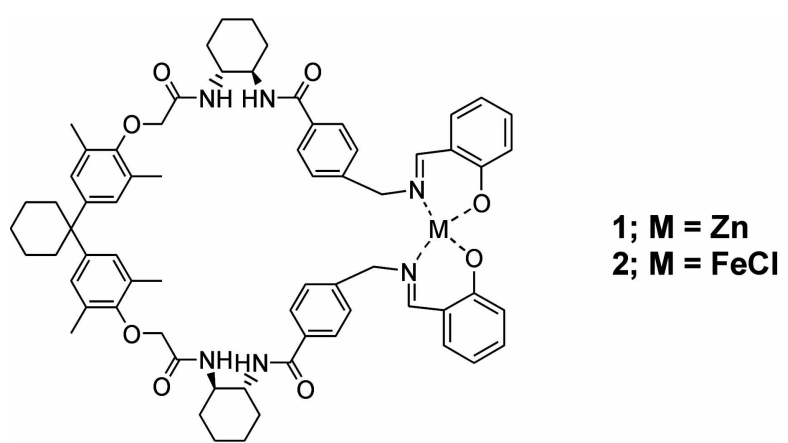

Scheme 1. Sequence Selective Peptide-binding Receptors ( 1 and 2).
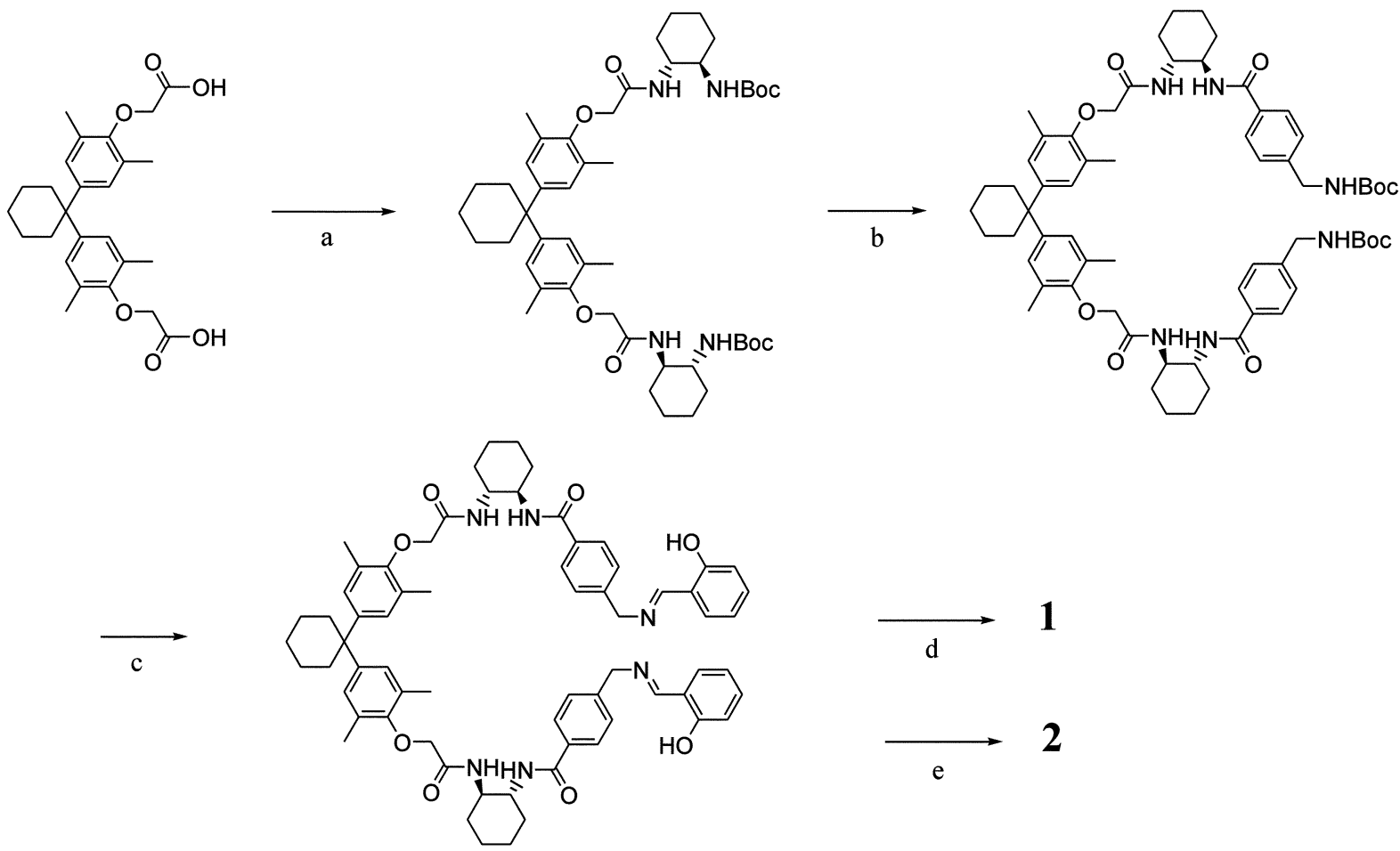

Scheme 2. Syntheses of Metallomacrocyclic Receptors (I and 2): (a) I)IC. IIOI3 I, mono-Hoc-(1R,2R)-1,2-diaminocyclohexane (78\%). (b)

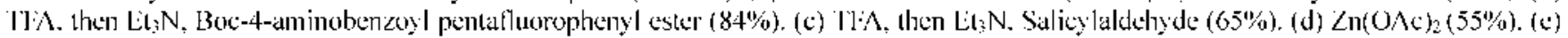
$\mathrm{FeC}]_{;}(53 \%)$. 
Table 1. Sequences (Resin-AA1-AA2-AA3-Ac) selected by binding assay with receptor (2)

\begin{tabular}{rlrl}
\hline 1 & (L)Gln-(D)Len-(L)Len & 7 & (D)Glu-(L)Ser-Gly \\
2 & (L)Ala-(D)Ser-Gly & 8 & (L)Ala-(D)His-Gly \\
3 & (D)Phe-(D)His-Gly & 9 & (L)Ala-(D)His-Gly \\
4 & (L)Ala-(D)Val-Gly & 10 & (L)Ala-(L)Phe-Gly \\
5 & (L)Ala-(L)Asn-Gly & 11 & (L)Ala-Gly-Gly \\
6 & (D)Val-(D)Lys-(D)Asp & 12 & (L)Ala-(D)Pro-Gly \\
\hline
\end{tabular}

certain metals can act chromogenic center and thus have the potential applicability for chenical sensors.

Syntheses of receptors ( 1 and 2 ) began with the preparation of the flexible ligand. DIC-promoted anide coupling reaction between bis-carboxylic acid ${ }^{3}$ and monoBoc-(IR,2R)-1.2-diaminocyclohexane and the subsequent reaction with Boc-4-aminobenzoyl pentafluorophenyl ester provide bis-anine intermediate. Bis-salicylidene inine ligand was prepared by heating the mixture of bis-anine intermediate and salicylaldehyde in ethanol. Metallontacrocycles were prepared by exploiting $\mathrm{Zn}$ (II), Fe(III)-salicylidene inine coordinate bond. The $\mathrm{Zn}(\mathrm{II})$ conplex $1^{4}$ was prepared as white solids with $55 \%$ y ield by mixing $1.0 \mathrm{eq}$. of $\mathrm{Zn}(\mathrm{OAc})_{2}$ and the corresponding ligand in ethanol. stirring for 3 hrs under reflux condition, then adding diethyl ether. The Fe(III) complexe 2 was prepared as dark red solids with $53 \%$ yield under the sinilar condition with $\mathrm{FeCl}_{3}$.

Recently. conbinatorial chemistry has become a nuajor tool in the elucidation of the binding properties of receptors. Macrocyclic compound (2) has the distinct color due to dye molecules and transition metals, and thus ideal for solid phase color binding assay using encoded combinatorial library of peptide substrates.

Macrocyclic compound (2) was screened against a tripeptide library on hydrophobic polystyrene in $\mathrm{CHCl}_{3}$. The library was prepared by encoded split synthesis and has the general structure Ac-AA3-AA2-AA1-NH( $\left.\mathrm{CH}_{2}\right)_{6}-\mathrm{C}(\mathrm{O}) \mathrm{NH}-$ Poly styrene. 67

Decoding the tripeptides on the colored beads by using electron capture gas chromatography revealed selective peptides-binding properties of macrocyclic compound (2). The most tightly binding substrates with macrocyclic compound (2) are shown in Table 1.

The binding data in Table 1 reveal a number of notable trends. For example. receptor 2 was found to bind strongly with the substrates with Gly (10 of 12) and (L)Ala ( 8 of 12) at $\mathrm{AA} 3$ and $\mathrm{AAl}$ positions respectively. However receptor 2 shows little selectivity for the residue at AA2 position.

To confirm the findings and to estimate the energetic extents of the selectivities observed the most tightly bound peptide with 2. Resin-(L)Ala-(L)Pro-Gly-Ac was resynthesized and its associations with 2 measured in $\mathrm{CHCl}_{3}{ }^{8}$ The binding energies were found to be $3.5 \mathrm{kcal} / \mathrm{mol}$. The other substrates found by binding assay are expected to have the similar range of binding energies. The binding energies with Resin-Gly-Gly-Gly-Ac. which is not found in assay. were found to be both less than $-0.5 \mathrm{kcal} / \mathrm{mol}$
In summary, the highly selective peptide-binding properties of synthetic receptors were elucidated by using a combinatorial method. Further studies on the structures of complexes between receptors and peptide substrates. and the peptide-binding properties of the other related synthetic receptors are in progress in this laboratory.

\section{Experimental Section}

Spectroscopic data of ligand ${ }^{9}:{ }^{1} \mathrm{H}$ NMR (DMSO-d 6 ) $\delta$ (ppm) 1.26-1.50 (m, 10H). 1.71-2.07 (m, 16H). 3.77 (m, $2 \mathrm{H}$ ). 3.92 (m. $2 \mathrm{H}$ ), 4.02 (dd, $4 \mathrm{H}, J=14.5,8.5 \mathrm{~Hz}), 4.84(\mathrm{~s}$, $4 \mathrm{H}) .6 .81(\mathrm{~s}, 4 \mathrm{H}) .6 .87(\mathrm{~d}, 2 \mathrm{H} . J=8.0 \mathrm{~Hz}) .6 .91(\mathrm{t}, 2 \mathrm{H} . J=$ $7.5 \mathrm{~Hz}$ ). 7.33 (t. $2 \mathrm{H}, J=7.5 \mathrm{~Hz}), 7.38$ (d, $2 \mathrm{H} . J=8.0 \mathrm{~Hz}$ ), 7.48 (dd. $2 \mathrm{H}, J=6.0,1.5 \mathrm{~Hz}$ ), 7.55 (d, $2 \mathrm{H}, J=7.5 \mathrm{~Hz}$ ). 7.76 (d, $4 \mathrm{H} . J=8.5 \mathrm{~Hz}), 8.22$ (d, $2 \mathrm{H} . J=8.5 \mathrm{~Hz}), 8.72(\mathrm{~s}, 2 \mathrm{H})$, 13.34 (s. 2H); IR (KBr) 3309. 2934. 1632. 1536. 1501, 1455 $\mathrm{cm}^{-1}$ : UV/Vis $\left(\mathrm{CH}_{2} \mathrm{Cl}_{2}\right.$ soln) $240,253.318 \mathrm{~nm}$. MS (FAB) $m z=1108\left(\mathrm{MH}^{+}\right)$.

Synthesis of 1 . To a solution of $100 \mathrm{mg}$ of ligand $(0.0703$ mmol) in $10 \mathrm{~mL}$ of $\mathrm{EtOH}$ was added $35 \mathrm{mg}$ of $\mathrm{Zn}(\mathrm{OAc})_{2}$ $(0.0705 \mathrm{mmol})$. After refluxing for $12 \mathrm{hr}$. the crude products were precipitated by adding ethyl ether. The crude products were recrystallized from EtOH/ethyl ether to give 1 as an anorphous white solid (45 $\mathrm{mg}, 55.0 \%$ ): ${ }^{\mathrm{H}} \mathrm{H}$ NMR (DMSOd $) \delta(p p m) 1.28-1.53$ (m. loH), 1.73-2.08 (m. 16H), 3.72 (m, 2H), $3.93(\mathrm{~m}, 2 \mathrm{H}), 3.96$ (dd. $4 \mathrm{H}, J=13.5 .8 .0 \mathrm{~Hz}), 4.32$ (dd. $4 \mathrm{H}, J=13.5,8.0 \mathrm{~Hz}), 6.52$ (t. $2 \mathrm{H}, J=8.5 \mathrm{~Hz}) .6 .54(\mathrm{~d}$, $2 \mathrm{H} . J=7.0 \mathrm{~Hz}$ ). 6.74 (s. $4 \mathrm{H}$ ). 7.13 (d. $4 \mathrm{H}, J=8.5 \mathrm{~Hz}) .7 .20$ (t. $2 \mathrm{H} . J=7.5 \mathrm{~Hz}) .7 .22(\mathrm{~d}, 2 \mathrm{H}, J=7.5 \mathrm{~Hz}), 7.52(\mathrm{~d}, 4 \mathrm{H}, J=$ $8.5 \mathrm{~Hz}$ ). $7.8 \mathrm{l}$ (d, $2 \mathrm{H} . J=7.5 \mathrm{~Hz}), 8.10$ (d. $2 \mathrm{H} . J=8.0 \mathrm{~Hz})$, $8.37(\mathrm{~s}, 2 \mathrm{H}):{ }^{12} \mathrm{C} \mathrm{NMR}\left(\mathrm{CDCl}_{3}\right) \delta(\mathrm{ppm}) 14.81,17.16 .23 .34$, 25.34. 25.69, 32.87, 37.86, 45.50. 53.12, 53.36, 64.11. 71.28. 115.64, 117.76. 118.72. 119.41. 128.25, 129.49 . $130.09,130.59 .134 .08,136.14,136.55,139.85,145.40$. 152.78, 166.83. 170.96, 171.88; IR (KBr) 3328, 2934. 1644. 1618. 1536, 1503, $1447 \mathrm{~cm}^{-1}$. UV/Vis $\left(\mathrm{CH}_{2} \mathrm{Cl}_{2}\right.$ soln) 239 , $273,376 \mathrm{~nm}: \mathrm{MS}(\mathrm{FAB}) m z=1170\left(\mathrm{MH}^{-}\right)$

Synthesis of 2. To a solution of $100 \mathrm{mg}$ of ligand $(0.00703$ mimol) in $10 \mathrm{~mL}$ of $\mathrm{EtOH}$ was added $12 \mathrm{mg}$ of $\mathrm{FeCl}_{3}$ $(0.00703 \mathrm{mmmol})$. After refluxing for $12 \mathrm{hr}$, the crude products were precipitated by adding ethyl ether. The cnude products were recrystallized from EtOH/ethyl ether to give 2 as an amorphous dark red solid (45 $\mathrm{mg} .53 .0 \%$ ): IR (KBr) 3325, 2934, 1654,1628,1560,1543 $\mathrm{cm}^{-1}$ : UV/Vis $\left(\mathrm{CH}_{2} \mathrm{Cl}_{2}\right.$ soln) $236.259 .521 .540 \mathrm{~nm}: \mathrm{MS}(\mathrm{FAB}) m z=1160(\mathrm{M}-\mathrm{Cl})^{-}$.

Acknowledgments. This work was supported by Korea Research Foundation (Grant No. 2000-015-DP0262).

\section{References and Notes}

1. Schneider, H.-J. Angew. Chent. Int. Ed. Engl. 1993, 32. 848; Molecular Recognition. Chemical and Biological Propblems: Roberts. S. M.. ed.: Royal Society ofChemistry: Cambridge. UK. 1989: Comprehensive Supramolecular Chemistry. Leht1. J.-M. Chair Ed.; Pergamon Press: Oxford, 1996; Vols 1-1 1: Kim, D.-H: Choi. M. J.: Chang. S.-K. Bull. Korean Chem. Soc. 2001, 22, 699. 
2. Still W. C. Acc. Chem. Res. 1996. 29, 155 and references therein 3. Diederich. F.: Dick. K.: Griebel. D. Chem. Ber. 1985. 118. 3588.

4. Since 1, 2 and its ligand were sparingly soluble in common organic solvents. it was not possible to study complexation properties of those by traditional spectroscopic titration methods.

5. Oldmever, M. H. J.: Swanson. R. N.: Dillard L. W.: Reader. J. C.: Asouline. G.: Kobavashi, R.: Wigler. M. Still. W. C. Proc. Natl. Acad Sci. USt 1993. 90. 10922: Jung. J. E.: Yoon. S. S. Bull. Korean Chem. Soc. 2002. 23. 1483; Jung. J. E.: Yoon. S. S. Bull. Korean Chem. Soc, 2002. 23. 1655.

6. AAn $=$ Anv possible combinations of $25(\alpha)$-annino acids such as
Gly, (L)Ala. (D)Ala. (L)Val. (D)Val, (L)Leu, (D)Leu. (L)Phe. (D)Phe. (L)Pro. (D)Pro. (L)Ser(OtBu). (D)Ser(OtBu). (L)AsprotBu). (D)Asp(OtBu). (L)Glu(OtBu). (D) $\mathrm{Glu}(\mathrm{OtBu}) . \quad$ (L) Ast1( $\mathrm{Tr})$. (D)Asnl(Tr). (L)Gin(Tr). (D)Gln(Tr). (L)Lys(Boc). (D)Lys(Boc). (L)His(Tr). (D)His(Tr). The number of members in substrates library is $(25)^{3} .15625$.

7. A total of 15 tag molecules (five tags for AAn) were used to encode the library according to the method reported in reference 5 .

8. Yoon. S. S.: Still. W. C. Tetrahedron 1995. 51. 567.

9. Kim. K.-J.; Yoon, S. S. Bull. Korean Chem. Soc. 1999, 20. 1387. 